\title{
The Alkaline Diet and the Warburg Effect
}

\author{
Hassan Bahrami, $\mathrm{PhD}$ \\ Independent health/nutrition researcher \\ hbahrami.research@gmail.com \\ Ted Greiner, $\mathrm{PhD}$ \\ Editor, World Nutrition \\ tedgreiner@yahoo.com
}

\section{Abstract}

The changing diets accompanying our modern life style have increased the content of foods that form acidic metabolic waste residues in the body. Wastes from these metabolic processes are released into the interstitial fluids and the blood, slightly changing their $\mathrm{pH}$ temporarily. This link may in turn have an impact on the incidence of non-communicable diseases (NCDs).

According to the Warburg Effect, an acidic cellular and circulatory environment may cause various specific health problems such as hypoxia and cancer, whereas an oxygen-rich optimumalkaline environment could retain healthy cells. However, the mechanisms by which the diet may be influential on blood $\mathrm{pH}$-related parameters and on health have remained largely unknown.

This paper begins with a detailed presentation of the concepts, issues and the existing evidence regarding alkaline and acid forming diets, and summarizes the three main mechanisms by which the diet influences the acid-base balance in the body. It then presents the findings of a small exploratory study in which one author (HB) followed diets traditionally thought to produce alkaline or acidic residues. After each diet period of one month (with a two-month wash out period), $\mathrm{pH}$, oxygen saturation, and carbon dioxide partial pressure were measured for arterial and for venous blood.

The resulting data indicated that the diets followed changed blood $\mathrm{pH}$-related parameters in the expected directions according to the acid-base theory of health. Increased intake of acid-forming foods resulted in a slightly lower $\mathrm{pH}$ level, but a significant reduction of oxygen saturation in the blood, whereas increased consumption of alkaline forming foods maintained the high oxygen saturation in the blood that, according to the Warburg Effect, may, if maintained, reduce the incidence of NCDs. Further cross-over research of this kind is needed, utilizing large samples and testing various dietary modifications. 


\section{Introduction}

\section{The impact of diet on the acid base balance in the body}

Diet is partially responsible for serious non-communicable diseases (NCDs) $[1,2,3,4,5,6]$, but the mechanisms for this epidemiological link are not well known. This paper explores the potential effect of diet on temporary $\mathrm{pH}$ imbalances at cellular and circulatory levels as a possible partial explanation for this link. In particular, this may be important in the development of cancer.

There are three major mechanisms by which the diet has an impact on the maintenance of the acid-base balance at various levels: (1) the varying impacts of diet on digestion, resulting in a temporary "acid tide" or "alkaline tide" in parts of the circulatory system, (2) the acidity or alkalinity of food and drink as ingested, and (3) temporary acid-base imbalances at cellular level caused by the $\mathrm{pH}$ of the residues produced in processes of respiration and other metabolic functions, which may be influenced by the overall diet, as well as exercise. The most powerful of the three is likely the third, which is also the most poorly researched and most often misunderstood. In the remainder of this introduction, we will summarize the major issues in acidbase balance and then describe these three mechanisms of $\mathrm{pH}$ regulation in detail.

\section{Basic acid-base issues}

The $\mathrm{pH}$ refers to the concentration of hydrogen ions in a solution, measured from 0 to 14 on a logarithmic scale, 0-7 being acidic and 7-14 being alkaline or base [7]. This may vary considerably from one area of the body to another. For example, the fluids in the stomach are very acidic $(\mathrm{pH} 1.5-3.5)$, but are neutralized when its contents enter the intestine, which is slightly alkaline [8].

The blood $\mathrm{pH}$ is normally maintained in the range of 7.35-7.45 [8]. The arterial blood is more alkaline and has a higher oxygen content than venous blood. If blood $\mathrm{pH}$ goes below 7.35, it is said to be acidic (acidemia), and if it goes above 7.45, it is alkalotic (alkalemia). A pH distant from this normal range means there is a severe, sometimes life-threatening acid-base disorder [9, $10]$.

Blood pH-related parameters are controlled by various buffering mechanisms in order to maintain the $\mathrm{pH}$ level within strict limits $[11,12,13,14,15,16]$. These include regulating concentrations of bicarbonates, alkali salts and acids, and adjusting saturations for oxygen and carbon dioxide [17].

The primary method of $\mathrm{pH}$ regulation is via an increased rate of respiration [16]. When carbon dioxide levels are excessive, faster breathing increases oxygen saturation and decreases carbon dioxide levels. This mechanism is rapid and partially overcomes the problem, but cannot safely be complemented via a conscious effort to breathe faster. 
The secondary mechanism that the body uses to deal with a longer term excessively acidic state is to excrete acids via the kidneys (in urine), via saliva, and through the skin (in sweat) $[11,18]$ and to reabsorb bicarbonate. If excess alkalinity is present, the kidneys excrete more bicarbonate into the urine $[16,17,19,20]$.

The tertiary mechanism of controlling blood $\mathrm{pH}$ over an even longer term is to use bone minerals such as calcium compounds in order to neutralize acids [21, 22]. However, this may result in reduction of bone density, and osteoporosis. There is also a risk of formation of kidney stones when excessive acid-forming foods and drinks are routinely consumed [23, 24].

Although these $\mathrm{pH}$ regulation mechanisms try to balance acidity levels, there are limitations to their functioning [24]. The response of the body to a metabolic acid load may not be immediate $[25,26,27]$ and during the time that the blood remains slightly acidic, a number of cells may be damaged, die or mutate [11]. In addition, the relatively high concentration of calcium ions released in response may precipitate in the kidneys or in blood vessels, partially blocking them and reducing the flexibility of their interior surfaces, resulting in increased blood pressure and cardiac health issues [28]. If the kidneys and lungs cannot keep the body $\mathrm{pH}$ in balance due to acidosis, this can cause inflammation of the veins or even coma [29].

Within the small changes of blood $\mathrm{pH}$ in the range 7.2-7.5, the concentration of oxygen and other blood gases may still vary, with potential long-term consequences for health [30]. While it is normal for relatively high concentrations of acids to form and $\mathrm{pH}$ to slightly drop around muscle cells during intense physical activity [25], here we are concerned with whether a long-term impact may result from acid-forming dietary habits and whether alkaline-forming diets can reduce these acidity levels and benefit health.

\section{The impact of diet on acid-base balance}

\section{Waste products of respiration at the cellular level}

The cells use nutrient molecules such as sugars, fatty acids and excess amino acids from the diet to produce energy [31]. The preferred source is glucose [32]. Other types of sugars we ingest include fructose and sucrose (found in sugarcane, sugar beets, as well as in fruits), maltose (found in barley), galactose and lactose (found in milk and dairy products), mannose (found in fruits and vegetables) [33], and trace amounts of N-Glycolylneuraminic acid (neu5Gc) from eating animals that metabolize it (humans do not)--which may be associated with cancer and other diseases [34, 35].

These nutrient molecules are converted into energy via cellular respiration processes that take place as aerobic where sufficient oxygen is available (healthier), but as anaerobic in the absence of adequate oxygen--in particular in muscles during high intensity exercise--producing lactic acid residues [36, 37]. The energy production from nutrient molecules also forms cell metabolic wastes as by-products $[14,15]$, which may include water, carbon dioxide, carbonic acid, lactic 
acid, bicarbonates, hydrochloric acid, sulphuric acid, phosphates and nitrogen compounds such as nitrates [38, 39, 40, 41, 42].

In aerobic respiration, the cellular fuels may be glucose, fatty acids or amino acids [13]. When cells use glucose as fuel, six molecules of oxygen are required for efficient combustion of each sugar molecule, as per the following equation [31, 32]:

Glucose (C6H12O6) + Oxygen (6 O2) $\rightarrow$ Energy + Carbon Dioxide (6 CO2) + Water (6 H2O)

However, where oxygen is not sufficient or it cannot reach the cells quickly enough to keep up with demand, conversion of glucose into energy inside the cells utilizes anaerobic respiration and fermentation processes. The following equation shows how energy is commonly produced from glucose in these processes [31, 32]:

Glucose (C6H12O6) $\rightarrow$ Energy + Lactic Acid (2 C3H6O3)

When other oxidants like nitrates are in excess, anaerobic respiration will not only form lactic acid as a metabolic waste [18], but also nitrogen wastes such as ammonia [39, 40]. In addition, the lactic acid from anaerobic respiration is more acidic than the carbonic acid from aerobic respiration $[40,43,44]$.

As by-products of cellular respiration, some foods may form acidic cell metabolic wastes (socalled acid-forming foods) and some may form alkaline cell metabolic wastes (so-called alkaline-forming foods), both temporarily affecting $\mathrm{pH}$ in some cellular environments and in blood compartments $[18,41]$. The characteristics of these cell metabolic wastes depend in large part on the chemical structure, digestive processes, and metabolic pathways related to each nutrient molecule $[32,36]$. The alkaline components of foods may include alkali salts such as potassium bicarbonate and potassium citrate, of which fresh vegetables and on-tree ripened natural fruits are good sources [41]. Acid-forming components of foods include protein, phosphate, and sulfur [18].

Amino acid metabolism releases hydrogen ions, causing a significant lowering of blood $\mathrm{pH}$. The quantity and type of acid released will depend on which amino acids are present: lysine, arginine, and histidine generate hydrochloric acid; cysteine and methionine, which contain sulfur, generate small amounts of sulfuric acid residues [41, 42].

In traditional systems of medicine, foods that tend to form acidic metabolic waste, such as animal protein, are thought to cause certain health problems when predominant in the diet [36, $40,42]$. Foods that form predominantly alkaline metabolic waste are believed to improve health and are even used in treatments for some diseases [41, 42]. But modern research is also beginning to confirm that these dietary differences do indeed influence the acid-base balance of several body compartments [25]. 


\section{The impact of diet on digestion-caused acid or alkali "tides" in the blood}

Via energy-expensive processes, the stomach converts salt, water and carbon dioxide into hydrochloric acid ( $\mathrm{pH} \sim 1)$, which creates a corresponding concentration of bicarbonate ions $\left(\mathrm{HCO}_{3}{ }^{-}\right.$with an alkaline $\left.\mathrm{pH}\right)$ that are secreted into the blood stream. As result, for a few hours, the venous blood around the stomach is more alkaline, referred to as the "alkaline tide" [26]. The pancreas also secretes additional bicarbonate into the duodenum [45] and a corresponding quantity of acid into the blood stream, causing a temporary 'acid tide' [27]. These $\mathrm{H}^{+}$ions eventually neutralize the earlier alkaline tide in the blood that was caused by the stomach [26]. These tides are also more gradually regulated by other $\mathrm{pH}$ regulation mechanisms as needed to maintain blood $\mathrm{pH}$ within normal parameters [26, 27].

For easy to digest meals (such as fruits and vegetables), the alkaline and acid tides are less extreme, because fewer hydrogen ions are needed for the stomach and fewer bicarbonate ions from the pancreas. But for heavy meals such as animal protein that require more acids to digest (or in the case of vomiting due to sickness or bulimia), these tides would be more pronounced, because the stomach has to produce greater amounts of acid [26]. Hence, frequent consumption of heavy meals may exacerbate acid-base disorders.

\section{The impact of the $\mathrm{pH}$ of foods ingested}

Alkaline supplements such as bicarbonate salts cannot be effectively used to alkalize the blood stream, as they are immediately neutralized by stomach acid. For the same reason, the body's cells do not receive any alkalinity directly from "alkaline-water" ( $\mathrm{pH}$ 8.5-9.0) that is sometimes advertised as a body alkalizing drink [46]. Indeed, as result of their neutralizing stomach acid, it is forced to produce extra acid, forming a temporary alkaline tide in the blood stream around the stomach as a by-product. If this increase in blood $\mathrm{pH}$ takes place at the same time as sustained high-intensity exercise, it may reduce the muscle pains associated with a high blood lactate response [47]. However, neutralizing the stomach acid may in the long term increase the risk of food- or water-borne illnesses by allowing bacteria to build up [48]. If the bicarbonate source is sodium, this may also contribute to blood pressure issues and even damage the stomach lining, increasing the risk of stomach cancer [49]. Bicarbonate salts may also cause mucosal damage to the gastrointestinal tract when used long-term, and even be life-threatening in patients with abnormal renal function or chronic kidney disease [50]. Of crucial importance in this context, the use of alkaline substances like bicarbonate cannot be an effective solution for diseases related to metabolic acidosis, as the alkaline tide that results from consuming them is short-term [27], but the body needs the sustained presence of normal alkalinity. In contrast to short-term approaches, high enough intake of alkaline foods or drinks over the long term, in particular those naturally rich in potassium bicarbonate, can help maintain this optimum alkaline environment.

Consuming too much acidic foods or drinks over a long period of time may also negatively affect stomach conditions as well as altering the body $\mathrm{pH}$. For instance, drinking too many acidic carbonated beverages may worsen acid reflux. Furthermore, they may increase body acidity, 
leading to reduced bone mineral density and increased risk of fracture [51]. This is probably because the pancreas has to produce more bicarbonates to neutralize the extra acids from the acid-rich carbonated drinks after they leave the stomach. Hence, a more significant acid-tide is experienced in venous circulation, which is neutralized by mobilizing minerals from bone. The same issue has been reported in case of chronic consumption $1000 \mathrm{mg}$ vitamin $\mathrm{C}$ supplements, which may eventually increase the risk of kidney stone formation [52].

Regardless of the original $\mathrm{pH}$ of the diet, acidic or alkaline metabolic wastes are formed at cellular level, and the $\mathrm{pH}$ of these residues (discussed in the next section) is independent of the total $\mathrm{pH}$ of the actual food or drink as consumed. Hence, while the $\mathrm{pH}$ of foods as ingested has impacts discussed above, the $\mathrm{pH}$ in body compartments at any one time is mainly dictated by the processes related to food digestion (acid and base 'tides') and the chemical reactions and products related to cellular respiration, rather than to the $\mathrm{pH}$ of their parent foods.

\section{Alkaline-Forming Diets}

The most poorly understood of the body's mechanisms for regulating acidity relates to the formation at cellular level of acidic or basic waste products of respiration or other metabolic functions, which we propose can be influenced by the composition of the diet. Some natural healers believe that acid-forming foods may play a large role in this, while alkaline-forming foods may be preventative $[41,53]$. This may be especially important in older people, because they gradually face loss of some renal acid-base regulatory function [22, 25].

Specific fruits and vegetables are commonly cited as healthy in the alternative medical literature $[41,46,53,54]$. For example, apples, oranges and green beans have a substantial content of mannose, a natural sugar that may slow down growth of tumors [33]. The alkalizing characteristics of fruits may depend on their content and composition and can even be affected by various production and harvest-related factors. The effect is different for climacteric fruits that can still ripen after being picked, versus non-climacteric fruits that can ripen little if at all once removed from the plant $[55,56]$. Early picking in this latter case may lead to less alkalizing characteristics and greater acidity [54]. On-tree ripened fruits may have higher levels of some minerals and vitamins [66], because some elements may further be translocated into the fruits from the leaves and possibly other parts of the plant [67]. In addition, fruit ripened under light has a higher sugar content [68] and lower acid content $[69,70]$.

Another factor traditionally thought to have an impact on the alkalizing effect of certain foods is the use of chemical fertilizers [62,63]. High nitrate intake may shift the body toward increased anaerobic respiration, increasing acid environments at cellular level, and fertilizer residues may add to this. To the extent that nitrates are converted into nitrites, they directly reduce the oxygencarrying capacity of the blood $[64,65]$.

A diet rich in alkaline-forming foods may also improve calcium balance and reduce risk for osteoporosis and stone formation in the kidneys by reducing bone resorption [42, 67, 68, 69]. In contrast, diet-induced metabolic acidosis is associated with increased risks of insulin resistance 
and type 2 diabetes [66]. Even some types of cancers have been linked to metabolic acidosis and acid-base imbalance [36, 37].

\section{Determining whether foods are acid or alkaline forming}

Understanding the acid and alkaline forming character of foods (independent from the original $\mathrm{pH}$ of the food or drink) requires measuring which foods have which kind of corresponding effect. One method would be to measure the $\mathrm{pH}$ of urine or saliva following consumption of each type of food. However, this is an indirect measurement and not very accurate because some of the metabolic wastes such as carbon dioxide leave the body via the lungs and blood acidity may partly be neutralized by bone calcium compounds; acidity of the saliva is usually neutralized by the teeth; and some acids are excreted via sweating $[11,16,13]$. Hence, the $\mathrm{pH}$ of neither urine nor saliva may be reliable indicators for blood $\mathrm{pH}[19,70]$.

Another approach is to estimate the acid/alkaline forming character of foods based on their composition [19, 53, 71]. Methods used include calculation of values for DAL (dietary acid load) or PRAL (potential renal acid load), NAE (net acid excretion) and EAA (excess acid/alkaline ash) for each foodstuff [19]. These methods are based on the composition of the food regarding magnesium, potassium, fiber, saturated fat, simple sugars, sodium, chloride, and protein/potassium ratios. For instance, the equation for calculating PRAL is $(\mathrm{mEq} / 100 \mathrm{~g})=0.49 \times$ protein $(\mathrm{g} / 100 \mathrm{~g})+0.037 \times$ phosphorous $(\mathrm{mg} / 100 \mathrm{~g})-0.021 \times$ potassium $(\mathrm{mg} / 100 \mathrm{~g})-0.026 \times$ magnesium $(\mathrm{mg} / 100 \mathrm{~g})-0.013 \times$ calcium $(\mathrm{mg} / 100 \mathrm{~g})$ [25]. The PRAL for vegetables is negative (indicating alkalinity), and for cheese and red meat, positive (indicating acidity) [41]. These values are in general agreement with the observations of urine $\mathrm{pH}$ when vegetable-rich or protein-rich diets are followed. EAA calculations are useful but not always predictive of urine $\mathrm{pH}$ [19]. None of these methods is comprehensive, each having their own limitations and uncertainties.

Another method used by natural health practitioners is Live (Cell) Blood Analysis [53]. However, this type of analysis is not accepted as a standard laboratory practice because its validity has not been established [72].

A more accurate technique than the ones discussed above is to directly measure venous blood $\mathrm{pH}$-related parameters following consumption of a specific food or diet [25]. Since the cell metabolic wastes are all excreted into the venous blood, taking a blood sample from the veins can more accurately indicate acidity of the metabolic wastes and provide more accurate and realistic results. To determine venous blood gas (VBG) parameters in a blood sample, $\mathrm{pH}$, oxygen saturation, and partial pressure of oxygen and carbon dioxide need to be measured [9, $10]$, and thus this may currently be considered to be too time-consuming and expensive to use in determining whether a large number of foods are acid- or alkali-forming (It would nevertheless be cost effective if future research suggests that alkaline-forming diets have a substantial impact in cancer prevention). In addition, the release of bone calcium or excretion of acids into the urine may eventually regulate the blood $\mathrm{pH}$ to a normal level, making the reliability of detecting acidosis based only on blood $\mathrm{pH}$ potentially inaccurate. However, in the short term, as mentioned 
above, the $\mathrm{pH}$ of cellular and circulatory environments will be influenced by the waste products of respiration and other metabolic processes and these in turn will be influenced by the food eaten within the past day or less. These temporary effects are what need to be measured; more research on humans is needed to determine the optimal time to take such measurements after meal consumption $[12,73,74]$.

Table 1 provides a categorized list of foods and drinks based on the effect they are thought to have on body $\mathrm{pH}$ (based on likely impact of metabolic residues). In each case, we have chosen the most reliable available data in the literature and performed a qualitative comparison based on agreements between the different references [19, 20, 41, 42, 46, 52, 53, 71]. However, most of these data came from sources which used measurement methods that have not been verified.

\section{The Warburg Effect on Acid-Base Disorders}

Cellular respiration requires appropriate conditions in terms of $\mathrm{pH}$, temperature, oxygen saturation, and concentration of essential minerals, vitamins, enzymes and co-enzymes in order to be effective and controlled [31,37]. If cellular respiration processes are disturbed or damaged, some cells may die. This is not a major problem, as long as not too many of them die, because they can be replaced. The potentially dangerous cells are the ones that mutate to survive such damage [75], developing into cancerous cells as a result of impaired respiration [76, 77].

Dr. Otto Warburg a German scientist, hypothesized that a repeatedly oxygen-poor, acidic cellular environment may result in acidosis in the micro-environment of tissues, damage the surrounding normal tissues, and cause cell mutations, leading towards cancer $[36,77,78]$. This so-called Warburg Effect is a form of modified cellular metabolism found in cancer cells, which tends to favor a specialized fermentation over the aerobic respiration pathway that most other cells of the body prefer.

Anaerobic respiration processes are faster but less efficient, and also consume greater amounts of glucose than aerobic respiration to produce similar levels of energy (ATP) [32]. Anaerobic respiration is found in virtually all tumors, which means cancer cells use larger amounts of sugars. Cancer cells may also use excessive quantities of other nutrients as well, including fats and some amino acids such as glutamine [79].

Cancer cells need large quantities of sugar to grow quickly and multiply at a fast rate, which takes a lot of energy. Hence, most simple tools for staging and diagnosis of cancer work by revealing the places in the body where cells are consuming extra sugar [79]. Thus, maintaining the blood sugar levels within the lower end of the healthy range (i.e., a fasting blood sugar of 72$79 \mathrm{mg} / \mathrm{dl}$ ) may weaken cancer cells, while normal cells can manage to survive such conditions $[76,80,81,82,83]$. In contrast, having too much sugar in the blood for long periods of time may favor cancer cells, as well as lead to other serious health problems such as heart disease, type 2 diabetes, and kidney disease $[76,80,84]$.

The Warburg Effect suggests that one of the conditions which favors growth of cancer cells is 
Table 1: Acid/Alkaline forming characteristics for certain foods $[19,20,41,42,46,52,53,71]$

\begin{tabular}{|c|c|c|c|c|c|c|}
\hline Category & $\begin{array}{l}\text { Strong Acid } \\
\text { (least } \\
\text { healthy) }\end{array}$ & Medium Acid & Weak Acid & $\begin{array}{l}\text { Weak } \\
\text { Alkaline }\end{array}$ & $\begin{array}{l}\text { Medium } \\
\text { Alkaline }\end{array}$ & $\begin{array}{c}\text { Strong } \\
\text { Alkaline } \\
\text { (healthiest) }\end{array}$ \\
\hline Fruits & $\begin{array}{c}\text { Prunes }^{1,2} \\
\text { Canned fruits } \\
\text { Factory } \\
\text { juices }{ }^{1,2}\end{array}$ & $\begin{array}{c}\text { Sour cherries } \\
1,2 \\
\text { Sour plums } \\
1,2,3,5\end{array}$ & $\begin{array}{c}\text { Sweat } \\
\text { Plums }{ }^{1,2}\end{array}$ & $\begin{array}{l}\text { Oranges }^{1,2,3} \\
\text { Bananas } \\
\text { Cherries }^{1,2,3,3} \\
\text { Peaches }^{1,2} \\
\text { Pomegranates }^{2}\end{array}$ & $\begin{array}{c}\text { Grapes }^{1,2} \\
\text { Apples }^{1,2} \\
\text { Pears }^{1,2} \\
\text { Melons }^{1,2} \\
\text { Raisins }^{1,2}\end{array}$ & $\begin{array}{c}\text { Lemons }^{1,2} \\
\text { Limes }^{1} \\
\text { Dates }^{1,2,5} \\
\text { Figs }^{1,2} \\
\text { Mangoes }^{1,2}\end{array}$ \\
\hline $\begin{array}{l}\text { Vegetable, } \\
\text { Beans, } \\
\text { Legumes }\end{array}$ & $\begin{array}{l}\text { Fried potatoes } \\
\text { and chips }\end{array}$ & $\begin{array}{c}\text { Peas }^{1} \\
\text { Lima beans }^{1} \\
\text { Lentils }^{1,2} \\
\text { Boiled } \\
\text { potatoes }^{1}\end{array}$ & $\begin{array}{c}\text { Kidney } \\
\text { beans }^{1} \\
\text { Cooked } \\
\text { vegetables }^{1}\end{array}$ & $\begin{array}{l}\text { Cucumber }^{1,3} \text {, } \\
\text { Carrots }^{1,2} \text {, } \\
\text { Tomatoes }^{1,2} \text {, } \\
\text { Mushrooms }^{1} \\
\text { Cabbage }^{1}, \\
\text { Green peas }^{1,2}\end{array}$ & $\begin{array}{c}\text { Olives }^{1} \\
\text { Green } \\
\text { Beans }^{1} \\
\text { Okra }^{1} \\
\text { Turnip }^{3} \\
\text { Celery }^{1,2,3} \\
\text { Pumpkin }^{2}\end{array}$ & $\begin{array}{c}\text { Garlic }^{1} \\
\text { Onions }^{1} \\
\text { Spinach }^{1,2,3}\end{array}$ \\
\hline $\begin{array}{l}\text { Nuts and } \\
\text { Seeds }\end{array}$ & $\begin{array}{l}\text { Peanuts }{ }^{1,2,3} \\
\text { Cashews }\end{array}$ & $\begin{array}{c}\text { Walnuts } \\
\text { Pistachios }{ }^{1,2,3}\end{array}$ & $\begin{array}{c}\text { Seeds: } \\
\text { Pumpkin }^{1,2} \\
\text { Sunflower }^{1} \\
\text { Sesame }^{1}\end{array}$ & - & - & $\begin{array}{c}\text { Raw } \\
\text { almonds } \\
1,2,3,5\end{array}$ \\
\hline Meats & $\begin{array}{c}\text { Pork meat }^{1,3} \\
\text { Shellfish }^{1} \\
\text { Rabbit }^{1,3} \\
\end{array}$ & $\begin{array}{c}\text { Beef }^{1,2,3} \\
\text { Lamb }^{1} \\
\text { Turkey }^{1} \text { Veal }^{1} \\
\end{array}$ & $\begin{array}{c}\text { Fish }^{1,2} \\
\text { Chicken }^{1,2}\end{array}$ & - & - & - \\
\hline $\begin{array}{l}\text { Eggs and } \\
\text { Dairy }\end{array}$ & $\begin{array}{c}\text { Cream }^{1,2} \\
\text { Ice Cream }^{1,2}\end{array}$ & $\begin{array}{c}\text { Homogenized } \\
\text { Cow's Milk1,2 } \\
\text { Cheese }^{1,2,3} \\
\text { Store eggs }{ }^{1,2}\end{array}$ & $\begin{array}{c}\text { Yogurt }^{1} \\
\text { Butter }^{1} \\
\text { Raw Milk } \\
\text { Farm } \\
\text { Eggs }^{1} \\
\end{array}$ & $\begin{array}{l}\text { Goat milk }{ }^{1,2} \\
\text { Goat cheese } \\
\qquad 1,2\end{array}$ & - & - \\
\hline $\begin{array}{l}\text { Grains } \\
\text { and } \\
\text { Cereals }\end{array}$ & $\begin{array}{c}\text { Pastries }^{1} \\
\text { Pasta }^{1} \text { Cereals } \\
{\text { (corn etc. })^{1}}^{\text {corn }}\end{array}$ & $\begin{array}{c}\text { White rice } \text { en }^{1,2} \\
\text { White flour }^{1,2} \\
\text { Oats }^{1,2} \\
\text { Bread }^{1,2}\end{array}$ & $\begin{array}{l}\text { Whole } \\
\text { wheat }^{1} \\
\text { Brown } \\
\text { rice }^{1,2}\end{array}$ & - & - & - \\
\hline Oils & Frying oil 1,2 & $\begin{array}{l}\text { Sunflower oil } \\
\text { Sesame oil }{ }^{1,2}\end{array}$ & - & - & - & Olive oil ${ }^{1}$ \\
\hline Drinks & $\begin{array}{c}\text { Liquor }^{1,2} \\
\text { Beer }^{1,2} \\
\text { Soft Drinks } \\
\text { Vitamin C } \\
\text { Supplements } \\
(1000 \mathrm{mg})^{4}\end{array}$ & $\begin{array}{c}\text { Black Tea }^{1,2} \\
\text { Coffee }^{1,2} \\
\text { Wine }^{1,2} \\
\text { Alkaline } \\
\text { water }^{1}\end{array}$ & $\begin{array}{l}\text { Bottled } \\
\text { mineral } \\
\text { water }^{1}\end{array}$ & $\begin{array}{c}\text { Spring } \\
\text { mineral } \\
\text { water }^{1} \\
\text { Ginger tea }^{1}\end{array}$ & $\begin{array}{l}\text { Lemon } \\
\text { juice } \\
\text { drink }^{1,2}\end{array}$ & - \\
\hline $\begin{array}{l}\text { Other } \\
\text { foods }\end{array}$ & $\begin{array}{c}\text { Chocolate }^{1,2} \\
\text { Ketchup }^{1,2} \\
\text { Mayonnaise }^{1,2}\end{array}$ & $\begin{array}{c}\operatorname{Jam}^{1,2} \\
\text { Sugar }^{1,2} \\
\text { Vinegar }^{1,2}\end{array}$ & $\begin{array}{l}\text { Processed } \\
\text { honey }\end{array}$ & $\begin{array}{l}\text { Ginger } \\
\text { Natural } \\
\text { honey }^{1}\end{array}$ & - & - \\
\hline
\end{tabular}

The above table has been integrated from several different sources, which include:

1- $\mathrm{pH}$ food chart published by Corriher [46]

2- $\mathrm{pH}$ food chart published by Bridgeford [53]

3- $\mathrm{pH}$ food chart published by Remer [71]

4- Thomas et al. [52]

5- Venous blood examination by the author (HB) to partially verify the table 
hypoxia. In contrast, an oxygen-rich, optimum-alkaline environment can maintain cells in a healthy state $[36,78,85]$. For this to be taken advantage of, appropriate conditions need to be provided internally around the cells by enhancing cellular respiration efficiency (i.e., aerobic instead of anaerobic) $[36,77,79]$. However, practical means of attaining this have been elusive. If both oxygen and carbon dioxide are provided, the blood tends to become more acidic, as the natural solubility of carbon dioxide in the blood is much higher than that of oxygen [74]. Yet long-term increases of oxygen intake via the lungs may result in oxygen toxicity or lung damage [86]. In addition, red blood cells' ability to carry oxygen from the lungs is limited. Using pressurized oxygen chambers may temporarily result in a small increase of arterial oxygen saturation [76], but is not a sustainable solution, and cannot help with a chronic acidic venous circulation.

Enthused by this still poorly understood Warburg Effect, some doctors have used it incorrectly, assuming mistakenly (as we explained above) that consumption of an alkaline substance would balance $\mathrm{pH}$ at cellular level. This has caused the death of some patients. In one case in 2012, for example, a 27-year-old British woman paid thousands of dollars to a doctor for alkaline treatment using baking soda (sodium bicarbonate), but after the treatment, her condition worsened due to severe alkalosis and soon afterwards she died [87].

Treatments of this kind were based on the incorrect belief that blood $\mathrm{pH}$ in cancer patients could be in the range of 4-5, hence, an extreme alkalinity can kill cancer cells [88]. But in fact, any blood $\mathrm{pH}$ less than 7.00 or above 7.65 is life-threatening and may result in death $[16,21,89]$.

In order to be effective, the alkalinity required by the Warburg Effect would have to utilize a precisely increased oxygen saturation in the blood around the affected body cells. This turn would require measuring and monitoring of blood $\mathrm{pH}$-related parameters to effectively overcome the acidity and provide a healthy body $\mathrm{pH}$ in the range of 7.40-7.45 [16, 82, 88].

In order to properly address the acid-base disorder based on blood $\mathrm{pH}$-related parameters, multiple blood parameters need to be measured. For instance, in normal people with a healthy blood $\mathrm{pH}$, the arterial oxygen saturation is usually high. But in patients diagnosed with hypoxia whose kidneys and lungs cannot keep the acid-base balance, there will usually be a drop of blood $\mathrm{pH}$ and a significant reduction in oxygen saturation (acidosis leading to hypoxia) [11, 12]. In some cases, blood $\mathrm{pH}$ may appear to be normal due to increased bicarbonate concentration by the kidneys or minerals released from bones into the blood, while oxygen saturation may still remain low (i.e., the acidosis is corrected, while hypoxia remains a major health issue) [13]. Oxygen saturation is also influenced by the quality of the blood cells, meaning that if many are damaged for any reason, the overall ability of the red blood cells to carry oxygen is reduced [14]. Acidosis due to acid forming dietary habits, even if mild, may worsen hypoxia $[15,4,5]$.

Perhaps an alkaline-producing diet could help achieve a balanced blood $\mathrm{pH}$, but first we must find out whether such a diet appears to have the expected effect. So far, there is little experimental evidence backing the claim made by some practitioners of traditional medicine that certain foods are acidic and others are basic with respect to the impact of their metabolic 
residues on biochemical parameters and thereby on indicators of $\mathrm{pH}$ in the blood. Hence, one of us (HB) experimented with such diets on himself, in hopes that this might help motivate other researchers to examine the issue in large-scale crossover trials.

\section{The Exploratory Study's methods}

The experimental subject (author HB) was a male, 37 years old, non-smoker, with a body mass index of 22-23, free of illness and in good physical condition according to blood examinations and a general health check-up performed prior to the experiment. In addition, he had not taken drugs or supplements of any kind for almost a year.

For the purpose of examining the effects on blood $\mathrm{pH}$ of alkaline forming and acid forming foods, the diets tested in the experiment were based in part on the foods labeled as alkaline or acid in Table 1. Substantial amounts of foods thought to be alkaline and acid forming, respectively, were added to his normal diet, with no attempt made to change other aspects such as total calorie intake. These diets were each consumed for one month and separated by a twomonth wash out period. Larger quantities of alkaline/acidic foods were consumed in the final week of each month.

The alkaline diet in first period consisted of increased quantities of those foods identified as such in Table 1 including on-tree ripened fruits, fresh raw leaf vegetables and natural plant-based foods in usual diets (boiled or steam-cooked), plus daily consumption of 5-10 raw almonds (produced without any fertilizers, as almonds are particularly susceptible to an increase in $\mathrm{HCN}$ content in the presence of excess nitrogen). The acid-forming diet in the second period consisted of increased quantities of those foods identified as such in Table 1, plus 4-6 sour plums per day (considered to be a strong acid-forming food).

Immediately after each of the month-long test periods, measurements were performed for blood $\mathrm{pH}$ and blood gas saturations and partial pressures. These measurements were performed for the arterial blood gases (ABG) and venous blood gases (VBG) separately. All the blood samples related to this study were taken and analyzed by Massoud Clinical Laboratory in Tehran, which provides comprehensive clinical services.

To check and confirm the reliability of the earlier tests for effect of alkaline diets, the experiment was repeated one year later on the same person. This time, only the alkaline diet was consumed for one month and only VGB was checked. This diet included daily consumption of approximately 10-15 dates (the Khasoei variety), 3-5 apples and 3-5 oranges (on-tree ripened), and the intake of alkaline foods in meals was increased as much as possible; acid-forming foods were minimized and any food with artificial sweeteners such as factory-juices, biscuits, soft drinks, cakes and chocolates were completely avoided. 


\section{Results}

The following measurements were taken and are reported here: venous and arterial blood samples following the acid forming diet, venous and arterial blood samples following the alkaline forming diet, and an additional venous blood sample following another experiment of alkaline diet alone; and $\mathrm{pH}$ of venous and arterial blood measurements taken after each diet. In addition, at the end of the second experiment, the fasting blood sugar concentration was 74 $\mathrm{mg} / \mathrm{dl}$, which is at the lower end of the healthy range, $72-99 \mathrm{mg} / \mathrm{dl}$.

Table 2 summarizes blood $\mathrm{pH}$, blood oxygen saturation, partial pressure of oxygen and partial pressure of carbon dioxide, and Figure 2 illustrates the relationships among the parameters. The relative difference in blood $\mathrm{pH}$ between the two measurement times was also determined and reported in Table 2 .

These results can be summarized as follows:

- The oxygen saturation of venous blood is always significantly lower than arterial blood, as should be the case.

- The acid-forming diet reduced the venous blood $\mathrm{pH}$ down to 7.30, compared to 7.42 after the alkaline-forming diet (typical venous blood $\mathrm{pH}$ on average is 7.35-7.40 according to the literature $[90,91,92,93,94,95])$, suggesting that the diet type could meaningfully change blood acidity level in the veins.

- Oxygen saturation of venous blood appears to be significantly lowered by an acid-forming diet down to $33 \%$, and increased following an alkaline-forming diet up to $81 \%$. Presumably, this is due to diet-related metabolic wastes from the cells excreted into the veins.

- The oxygen saturation of arterial blood from acid-forming diet to alkaline-forming diet, increased from $94 \%$ to $98 \%$. The change in oxygen saturation in arteries due to change of diet type is expected to be minor and in any case is already close to the theoretical ceiling of $100 \%$.

- The alkaline-forming diet appeared to increase partial pressure of oxygen and also reduce partial pressure of carbon dioxide in both arterial and venous blood.

These data were all from measurements taken at a laboratory located in Tehran, around $1500 \mathrm{~m}$ above the sea level. At higher altitudes, carbon dioxide loss is slightly greater, and entry of oxygen from the air into the blood is slightly reduced [96, 97, 98, 99, 100]. For instance, based on the literature, the commonly reported range for partial pressure of carbon dioxide at sea level is around $40-45 \mathrm{mmHg}$ and at $1500 \mathrm{~m}$ above sea level is about $35-40 \mathrm{mmHg}$. Hence, the above values should be looked at with this expected effect of altitude on overall typical ranges. 
Table 2: Blood gases and $\mathrm{pH}$ for the candidate from a single blood draw after one month on each diet

\begin{tabular}{|c|c|c|c|c|c|c|c|}
\hline $\begin{array}{l}\text { Blood } \\
\text { type }\end{array}$ & Diet type & Blood pH & $\begin{array}{c}\Delta(\mathbf{p H})= \\
\mathrm{pH}-7.4\end{array}$ & $\begin{array}{l}\mathrm{PCO}_{2} \\
\mathrm{mmHg}\end{array}$ & $\begin{array}{c}\mathrm{P} \mathrm{O}_{2} \\
\mathrm{mmHg}\end{array}$ & $\mathrm{HCO}_{3}$ & $\begin{array}{c}\text { Oxygen } \\
\text { Saturation \% }\end{array}$ \\
\hline \multirow{2}{*}{ Arterial } & $\begin{array}{l}\text { Alkaline- } \\
\text { forming }\end{array}$ & 7.47 & +0.07 & 31 & 111 & 25 & 98 \\
\hline & Acid-forming & 7.44 & +0.04 & 37 & 67 & 25 & 94 \\
\hline \multirow{3}{*}{ Venous } & $\begin{array}{l}\text { Alkaline- } \\
\text { forming }\end{array}$ & 7.42 & +0.02 & 35 & 44 & 24 & 81 \\
\hline & Acid-forming & 7.30 & -0.1 & 53 & 22 & 23 & $33^{\mathrm{a}}$ \\
\hline & $\begin{array}{l}\text { Alkaline- } \\
\text { forming ( } 2^{\text {nd }} \\
\text { experiment })\end{array}$ & 7.40 & 0 & 34 & 43 & 21 & 79 \\
\hline \multicolumn{2}{|c|}{$\begin{array}{c}\text { Typical common ranges for } \\
\text { VBG parameters }\end{array}$} & $7.35-7.41$ & - & $35-45$ & $35-45$ & $21-29$ & $60-85$ \\
\hline
\end{tabular}

${ }^{a}$ While this value appears to be far below the commonly measured ones, we checked and several people with largely acid-forming diets had similar values.

b These ranges come from combining various sources of published data from different laboratories, as each has reported the normal range differently [90, 91, 92, 93, 94, 95].

\section{Discussion and conclusions}

Of course, this study was extremely limited in scope, with an $n$ of only one and measurements only taken after each diet, not before the diets. This exploratory study found the hypothesized relationship between diet type with $\mathrm{pH}$ and oxygen saturation of venous blood, suggesting that these parameters are significantly affected by diet type. It also suggests that the type of diet chosen was effective and the data consulted from acid/alkaline forming food tables are plausible.

The present study was intended to provide data on a first-time basis to determine whether a fullblown study might be justifiable of the potential of using an alkaline diet to achieve improved 
health and prevention of disease, as predicted by the Warburg Effect. We hope this will inspire future researchers to conduct cross-over trials on an adequate sample size.

Figure 1: Relationship between blood $\mathrm{pH}$ and oxygen saturation for the venous and arterial blood samples

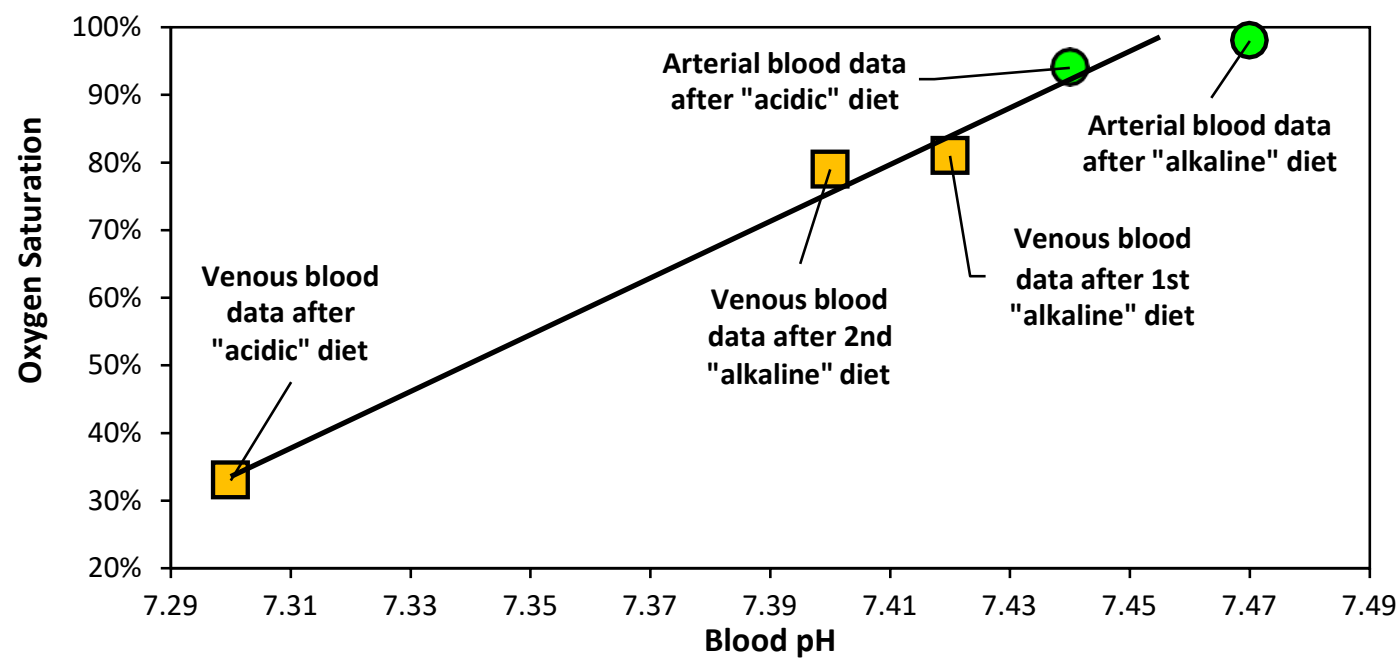

\section{Acknowledgments}

We would like to acknowledge and show our gratitude to International Agency for Research on Cancer (IARC), Cancer Research UK, Dr. Rachel Thompson (World Cancer Research Fund's), Dr. Gordon Edwards (Canadian Coalition for Nuclear Responsibility), Thomas Corriher (HealthWyze USA), Dr. Ali Karami (National Foundation of Healthy Lifestyle), Dr. Roghayeh Javanmard and Mazdafar Momeni for sharing valuable information that were used in the study.

We are also thankful to Hanieh Habibfar, Kian Bahrami, Nikan Bahrami, Radin Shouri, Chantele Siavoshi, Lucas Waters, Gemma Byfield, Sahar Mosaffa, Soraya Mohamadzadeh and Maryam Alibeigi for their great help and support in the research work.

\section{References}

1- Robey I.F. (2012). "Examining the relationship between diet-induced acidosis and cancer." Nutr Metab 9:72. https://doi.org/10.1186/1743-7075-9-72

2- Chiche, J. et al. (2010). "Tumour hypoxia induces a metabolic shift causing acidosis: a common feature in cancer." Journal of Cellular and Molecular Medicine 14(4):771-94. (doi: 10.1111/j.1582-4934.2009.00994.x)

3- Lo J.J., Park Y.M. (2020). “Association between meat consumption and risk of breast cancer: Findings from the Sister Study.” International Journal of Cancer 146(8):2156-2165. https://doi.org/10.1002/ijc.32547 
4- Strober J.W., Brady M.J. (2019). "Dietary Fructose Consumption and Triple-Negative Breast Cancer Incidence.” Frontiers in Endocrinology 10:367. (doi: 10.3389/fendo.2019.00367)

5- Huang Sh., Tang Y. (2016). "Acidic extracellular $\mathrm{pH}$ promotes prostate cancer bone metastasis.” Oncology Reports 36(4):2025-2032. https://doi.org/10.3892/or.2016.4997

6- Chan J.M., Stampfer M.J. (2001). "Dairy products and prostate cancer risk." The American Journal of Clinical Nutrition 74(4):549-554.

7- Buck P., et al. (2002). "Measurement of pH: definition, standards and procedures." Pure Appl Chem 74(11):2169-2200.

8- Surat, P. (2021). "pH in the Human Body." News Medical, 21 February. https://www.newsmedical.net/health/pH-in-the-Human-Body.aspx

9- Springhouse (1999). "Handbook of Diagnostic Tests." 2nd edition, Springhouse Co. ISBN-13: 978-0874349825.

10- Brunner L.S. \& Suddarth D.S. (1999). “The Lippincott Manual of Nursing Practice.” JB Lippincott.

11- Hamilton P.K., Morgan N.A. (2017). “Understanding Acid-Base Disorders.” Ulster Medical Society Journal 86(3):161-166.

12- Swenson E.R. (2016). "Hypoxia and Its Acid-Base Consequences: From Mountains to Malignancy." Journal of Advances in Experimental Medicine and Biology 903:301-23. (doi: 10.1007/978-1-4899-7678-9_21).

13- Patel S, Sharma S. (2020). "Respiratory Acidosis.” StatPearls publishing. https://www.ncbi.nlm.nih.gov/books/NBK482430/

14- HospiMedica international staff. (2020). "COVID-19 Patients Have Low Oxygen Levels Due to Damaged Blood Cells, Finds Study.” https://www.hospimedica.com/covid19/articles/294783369

15- Arnett TR (2010). “Acidosis, hypoxia and bone.” Arch Biochem Biophys 2010, 503 (1): 103-109. (DOI: 10.1016/j.abb.2010.07.021).

16- Singh V., Khatana S.H., and Gupta P. (2013). "Blood gas analysis for bedside diagnosis." National Journal of Maxillofacial Surgery 4(2):136-141. (doi: 10.4103/0975-5950.127641).

17- Hopkins E., Sanvictores T., Sharma S. (2020). "Physiology, Acid Base Balance.” StatPearls Publishing. https://www.ncbi.nlm.nih.gov/books/NBK507807

18- Schwalfenberg G.K. (2012). "The Alkaline Diet: Is There Evidence That an Alkaline pH Diet Benefits Health?” Journal of Environmental and Public Health 2012:727630. (doi: 10.1155/2012/727630)

19- Ausman L.M., Oliver M.L., et al. (2008). "Estimated net acid excretion inversely correlat1es with urine $\mathrm{pH}$ in vegans, lacto-ovo vegetarians, and omnivores." Journal of Renal Nutrition 18(5):456-65. (doi: 10.1053/j.jrn.2008.04.007)

20- Parmenter B.H., Dymock M., et al. (2020). "Performance of predictive equations and biochemical measures quantifying net endogenous acid production and the potential renal acid load." Kidney International Reports 5(10):1738-1745. https://doi.org/10.1016/j.ekir.2020.07.026 
21- Hamm L.L., Nakhol N. (2015). “Acid-Base Homeostasis.” Clinical Journal of the American Society of Nephrology 10(12):2232-42. (doi: 10.2215/CJN.07400715).

22- Leech J. (2019). "The Alkaline Diet: An Evidence-Based Review."

https://www.healthline.com/nutrition/the-alkaline-diet-myth

23- Koeppen B.M. (2009). "The kidney and acid-base regulation.” Advances in Physiology Education 33(4):275-281. https://doi.org/10.1152/advan.00054.2009

24- Fenton T., Tough S. (2011). "Causal assessment of dietary acid load and bone disease: a systematic review \& meta-analysis applying Hill's epidemiologic criteria for causality." Nutrition Journal 10:41. (doi: 10.1186/1475-2891-10-41)

25- Hietavala E.M., Stout J.R. et al. (2014). "Effect of diet composition on acid-base balance in adolescents, young adults and elderly at rest and during exercise." European Journal of Clinical Nutrition 69:399-404. https://doi.org/10.1038/ejcn.2014.245

26- Smith M.E., Morton D.G. (2011). "The Digestive System: Systems of the Body Series.” Elsevier Health Sciences UK. p. 52-85. ISBN 978-0-7020-4841-8.

27- Smith M.E., Morton D.G. (2010). “The Digestive System.” (Second Edition), Churchill Livingstone (eBook, ISBN: 9780702048418).

28- Alexander S., Ostfeld R.J., Allen K., Williams K.A. (2017). “A plant-based diet and hypertension.” Journal of Geriatric Cardiology 14(5):327-330. (doi: 10.11909/j.issn.16715411.2017.05.014)

29- Jung B., Martinez M., Claessens Y. et al. (2019). "Diagnosis and management of metabolic acidosis: guidelines from a French expert panel.” Ann. Intensive Care 9:92. https://doi.org/10.1186/s13613-019-0563-2

30- Collins J.A., Rudenski A. (2015). "Relating oxygen partial pressure, saturation and content: the hemoglobin-oxygen dissociation curve." Breathe Journal 11(3):194-201.

31- Cooper M.G., Housman R.E. (2009). “The Cell: A Molecular Approach.” Fifth Edition, Publisher: Sinauer Associates, Inc. (ISBN-13: 978-0878933006).

32- Nelson D.L. (2012). "Lehninger Principles of Biochemistry." Sixth edition, published by W.H. Freeman.

33- Gonzalez P.S., O’Prey J., Cardaci, S. et al. (2018). "Mannose impairs tumor growth and enhances chemotherapy.” Nature 563:719-723. (doi: 10.1038/s41586-018-0729-3)

34- Samraj A., Pearce O. (2015). “A red meat-derived glycan promotes inflammation and cancer progression." Proceedings of the National Academy of Sciences 112(2):542-7. (doi: 10.1073/pnas.1417508112).

35- Alisson-Silva F., Kawanishi K., \& Varki A. (2016). "Human risk of diseases associated with red meat intake: Analysis of current theories and proposed role for metabolic incorporation of a non-human sialic acid.” Molecular Aspects of Medicine 51:16-30. https://doi.org/10.1016/j.mam.2016.07.002

36- Kobayashi Y., Banno K. (2018). "Warburg effect in Gynecologic cancers." Journal of Obstetrics \& Gynecology Research 45(3):542-548. (doi: 10.1111/jog.13867) 
37- Lodish H.F., et al. (2016). "Molecular Cell Biology." 7th ed., W. H. Freeman and Company. pp. 520-523. ISBN 978-1-4292-3413-9

38- Fadaka A. (2017). "Biology of glucose metabolization in cancer cells." Journal of

Oncological Sciences 3:45e514. (DOI: 10.1016/j.jons.2017.06.002)

39- Wright P.A. (1995). "Nitrogen excretion." Journal of Experimental Biology 198:273-281.

40- Nnate D., Achi N.K. (2016). "Nitrate Metabolism: A Curse or Blessing to Humanity?"

Journal of Scientific Research and Reports 11(4):1-19. (DOI: 10.9734/JSRR/2016/26773).

41- Angeloco L.R.N., Souza G.C.A. (2017). "Alkaline Diet and Metabolic Acidosis: Practical

Approaches to the Nutritional Management of Chronic Kidney Disease." Journal of Renal

Nutrition 28(3):215-220. (DOI: 10.1053/j.jrn.2017.10.006)

42- Yari Z, Mirmiran P. (2018). "Alkaline Diet: A Novel Nutritional Strategy in Chronic Kidney

Disease?" Iranian Journal of Kidney Diseases 12(4):204.

43- Voet, Donald \& Voet, Judith G. (1995). Biochemistry (2nd ed.). New York, NY: John Wiley

\& Sons. ISBN 978-0-471-58651-7.

44- Pines D. et al. (2016). "How Acidic Is Carbonic Acid?” Journal of Physical Chemistry B 120(9):2440-51. (doi: 10.1021/acs.jpcb.5b12428)

45- Shiguro H., Yamamoto A., Nakakuki M., et al. (2012). "Physiology and pathophysiology of bicarbonate secretion by pancreatic duct epithelium.” Nagoya J Med Sci 74(1-2):1-18.

46- Corriher, Thomas (2009). "pH Food Chart." HealthWyze website. https://healthwyze.org 47- Koziris, L. (2012), "Sodium Bicarbonate Supplementation: It's Worth Another Chance."

Strength and Conditioning Journal 34(4):21. (doi: 10.1519/SSC.0b013e318259401a)

48- Smith J.L. (2003). "The role of gastric acid in preventing foodborne disease and how bacteria overcome acid conditions." J Food Prot 66(7):1292-303. (doi: 10.4315/0362-028x-66.7.1292)

49- Ge S., Feng X., Shen L., Wei Z., Zhu Q., Sun J. (2012). "Association between habitual dietary salt intake and risk of gastric cancer: A systematic review of observational studies." Gastroenterol Res Pract 2012:808120. (doi: 10.1155/2012/808120)

50- Gonzalez G.B., Pak C.Y., Adams-Huet B., Taylor R., Bilhartz L.E. (1998). "Effect of potassium-magnesium citrate on upper gastrointestinal mucosa." Aliment Pharmacol Ther 12(1):105-10. (doi: 10.1046/j.1365-2036.1998.00280.x)

51- Chen L., Liu R., Zhao Y., Shi Z. (2020). "High Consumption of Soft Drinks Is Associated with an Increased Risk of Fracture: A 7-Year Follow-Up Study." Nutrients 12(2):530. (doi: 10.3390/nu12020530)

52- Thomas L.D.K., Elinder C., Tiselius H., Wolk A., Åkesson A. (2013). "Ascorbic Acid Supplements and Kidney Stone Incidence Among Men: A Prospective Study.” JAMA Intern Med. 173(5):386-388. (doi: 10.1001/jamainternmed.2013.2296)

53- Bridgeford R. (2015). "The Definitive Acid \& Alkaline Food Chart." Version 4.0 updated June 2015. https://liveenergized.com/wp-content/uploads/2015/06/alkaline-food-chart-4.0.pdf 54- Sangma J.J., Suneetha J., Kumari B.A. (2019). "Concepts of acid alkaline diet.” The Pharma Innovation Journal 8(4):932-935 
55- Abell C. (2017). "Ripening 101: Climacteric vs. Non-Climacteric Fruits.” Food and Nutrition website. https://foodandnutrition.org/blogs/student-scoop/ripening-101-climacteric-vs-nonclimacteric-fruits/

56- Paul V., Pandey R. (2012). "The fading distinctions between classical patterns of ripening in climacteric and non-climacteric fruit and the ubiquity of ethylene-An overview." Journal of Food Science and Technology 49(1):1-21. (doi: 10.1007/s13197-011-0293-4)

57- Rabaya T., Samad M.A. (2017). "Study of Artificial Ripening Agent and Its Effects on Banana (Musa spp.) Collected from Tangail Area, Bangladesh.” Journal of Environmental Science, Toxicology and Food Technology 11(9):14-19.

58- Murneek A.E., Maharg L. (1954). "Ascorbic Acid (Vitamin C) Content of Tomatoes and Apples.” Research Bulletin 568:4, College of Agriculture, University of Missouri.

59- Özdemir I.S. (2015). "Effect of light treatment on the ripening of banana fruit during postharvest handling." Journal of Fruits 71(2):115-122.

60- Batista-Silva, W., et al. (2018). "Modifications in Organic Acid Profiles During Fruit Development and Ripening: Correlation or Causation?” Frontiers in Plant Science 9:1689. (doi: 10.3389/fpls.2018.01689)

61- Anthon G.E., Strange M.L. (2011). “Changes in pH, acids, sugars and other quality parameters during extended vine holding of ripe processing tomatoes." Journal of the Science of Food and Agriculture 91(7):1175-81. (DOI: 10.1002/jsfa.4312).

62- Atafar Z., Nouri J. (2009). "Effect of fertilizer application on soil heavy metal concentration." Journal of Environmental Monitoring and Assessment 160(1-4):83-9.

63- Carver A. and Gallicchio V.S. (2017). "Heavy Metals and Cancer." In: Cancer Causing Substances, pp 1-9. (DOI: 10.5772/intechopen.70348).

64- Daniel F Gomez Isaza, Rebecca L Cramp, Craig E Franklin (2020), "Simultaneous exposure to nitrate and low $\mathrm{pH}$ reduces the blood oxygen-carrying capacity and functional performance of a freshwater fish." Conservation Physiology 8(1):coz092. https://doi.org/10.1093/conphys/coz092

65- Helms et al. (2018). "Erythrocytes and Vascular Function: Oxygen and Nitric Oxide."

Frontiers in Physiology, Vol 9. (DOI: 10.3389/fphys.2018.00125)

66- Won K.L., Shin D. (2020). "Positive association between dietary acid load and future insulin resistance risk: findings from the Korean Genome and Epidemiology Study." Nutrition Journal 19:137. https://doi.org/10.1186/s12937-020-00653-6

67- Burckhardt P. (2008). "The effect of the alkali load of mineral water on bone metabolism: Interventional studies." Journal of Nutrition 138:435S-437S.

68- Heaney R.P. and Layman D.K. (2008). "Amount and type of protein influences bone health." American Journal of Clinical Nutrition 87(Suppl.):1567S-70S.

69- Lambert H., Frassetto L. (2015). "The effect of supplementation with alkaline potassium salts on bone metabolism: a meta-analysis." Osteoporosis International 26:1311-1318. (doi: 10.1007/s00198-014-3006-9) 
70- Barsanti J.A. (2012). "Small Animal Clinical Diagnosis by Laboratory Methods." (Fifth Edition), Pages 126-155, Imprint: Saunders (eBook, ISBN: 9781455755028).

71- Remer T. F. (1995). "Potential renal acid load of foods and its influence on urine pH." Journal of the American Dietetic Association 95(7):791-797.

72- U.S. Department of Health and Human Services. (2001). "CLIA regulation of unestablished laboratory tests." https://permanent.fdlp.gov/gpo73443/oei-05-00-00250.pdf

73- Frassetto L., Banerjee T. (2018). “Acid Balance, Dietary Acid Load, and Bone Effects-A Controversial Subject.” Nutrients Journal 10(4):517. (doi: 10.3390/nu10040517)

74- Christmas K.M. (2017). "Equations for O2 and CO2 solubilities in saline and plasma." Journal of Applied Physiology 122(5):1313-1320. (doi: 10.1152/japplphysiol.01124.2016)

75- Edwards G. (1992). “Uranium: Known Facts and Hidden Dangers.” Address at The World Uranium Hearings, Salzburg. http://www.ccnr.org/salzburg.html

76- Seyfried T.N., Shelton L.M. (2010). “Cancer as a metabolic disease.” Nutrition \& Metabolism 7:7. (doi: 10.1186/1743-7075-7-7)

77- Epstein T., Gatenby R.A., Brown J.S. (2017). "The Warburg effect as an adaptation of cancer cells to rapid fluctuations in energy demand." PLoS ONE 12(9):e0185085. (DOI: 10.1371/journal.pone.0185085)

78- Otto A.M. (2016). "Warburg effect(s) — a biographical sketch of Otto Warburg and his impacts on tumor metabolism." Cancer and Metabolism 4:5. (doi: 10.1186/s40170-016-01459)

79- Vander Heiden, M.G. et al. (2009). "Understanding the Warburg effect: the metabolic requirements of cell proliferation." Science 324(5930):1029-33. (doi:

$10.1126 /$ science.1160809)

80- Bullen J. (2017). “Cancer and sugar: Does changing your diet starve cancerous cells?” ABC Health \& Wellbeing. https://www.abc.net.au/news/health/2017-07-26/cancer-and-sugar-whatyou-need-to-know/8701870

81- Apple S. (2016). “An old idea, Revived: Starve Cancer to Death.” The New York Times Magazine, 12 May 2016. https://www.nytimes.com/2016/05/15/magazine/warburg-effect-anold-idea-revived-starve-cancer-to-death.html?searchResultPosition=1

82- Harrison C. (2017). "The Warburg Effect: Can Cancer Be Starved of Sugar?" Cancer Therapy Advisor. https:/www.cancertherapyadvisor.com/home/cancer-topics/generaloncology/the-warburg-effect-can-cancer-be-starved-of-sugar/

83- Bauersfeld S.P., Kessler C.S. (2018). "The effects of short-term fasting on quality of life and tolerance to chemotherapy in patients with breast and ovarian cancer: a randomized cross-over pilot study." BMC Cancer Journal 18:476. (DOI: 10.1186/s12885-018-4353-2)

84- Sonestedt, E. et al. (2012). "Does high sugar consumption exacerbate cardiometabolic risk factors and increase the risk of type 2 diabetes and cardiovascular disease?" Food \& Nutrition Research 56(1):19104. (doi: 10.3402/fnr.v56i0.19104). 
85- Höckel M., Vaupel P. (2001). "Tumor Hypoxia: Definitions and Current Clinical, Biologic, and Molecular Aspects." Journal of the National Cancer Institute 93(4):266-276. https://doi.org/10.1093/jnci/93.4.266

86- Chawla A., Lavania A.K. (2001). “Oxygen toxicity.” Medical Journal Armed Forces India 57:131-3. (doi: 10.1016/S0377-1237(01) 80133-7).

87- MacMillan A. (2017). "The doctor behind the alkaline diet is facing jail time." https:/www.foxnews.com/health/the-doctor-behind-the-alkaline-diet-is-facing-jail-time 88- Corriher, Th., 2010. “The Cancer Report.” Health Wyze website. https://www.healthwyze.org/

89- Tripathy S. (2009). "Extreme metabolic alkalosis in intensive care." Indian J Crit Care Med 13(4):217-220. (doi: 10.4103/0972-5229.60175)

90- Mohammed H.M., Abdelatief D.A. (2016). "Easy blood gas analysis: Implications for nursing." Egyptian Journal of Chest Diseases and Tuberculosis 65(1):369-376. https://doi.org/10.1016/j.ejcdt.2015.11.009

91- Elezagic D., et al. (2021). "Venous blood gas analysis in patients with COVID-19 symptoms in the early assessment of virus positivity." Journal of Laboratory Medicine 45(1):27-30. https://doi.org/10.1515/labmed-2020-0126

92- Chung PA, Scavone A, Ahmed A, Kuchta K, Bellam SK. (2019). “Agreement and Correlation of Arterial and Venous Blood Gas Analysis in a Diverse Population.” Clinical Medicine Insights: Trauma and Intensive Medicine 10:1179560319846452. (doi: 10.1177/1179560319845869)

93- Adhikari S., et al. (2015). "Correlation of arterial blood gas measurement with peripheral venous blood gas values in adult patients admitted in ICU." Journal of Chitwan Medical College 5(13):11-17. https://www.researchgate.net/publication/324170190_correlation_of_arterial_blood_gas_mea surement with peripheral venous blood gas values in adults patients admitted in icu

94- Orucova H., et al. (2019). "Comparison of arterial and venous blood gases in patients with obesity hypoventilation syndrome and neuromuscular disease." Journal of Annals of Thoracic Medicine 14(3):192-197. (DOI: 10.4103/atm.ATM_29_19)

95- Lavazieh Lab reference ranges for ABG/VBG parameters. (www.lavaziehlab.com)

96- Peacock AJ. (1998). “ABC of oxygen: oxygen at high altitude.” BMJ 317(7165):1063-1066. (doi: 10.1136/bmj.317.7165.1063)

97- Morris A. (1984). "Clinical pulmonary function tests: A manual of uniform lab procedures." Salt Lake City, Intermountain Thoracic Society.

98- Sutton JR, Reeves JT, Wagner PD, et al. (1988). "Operation Everest II: Oxygen transport during exercise at extreme simulated altitude.” J Appl Physiol 64:1309.

99- Shiraki K, Yousef MK. (1987). "Man in stressful environments.” Springfield, Ill, 1987, Thomas; pp 199-232.

100- McFarland RA, Dill DB. (1938). "A comparative study of the effects of reduced oxygen pressure on man during acclimatization.” J Aviat Med 9:18-44. 